\title{
PENERAPAN REALISTIC MATHEMATICS EDUCATION (RME) DI SEKOLAH DASAR
}

\author{
Dyah Anungrat Herzamzam ${ }^{1_{*}}$, Ilmi Noor Rahmad ${ }^{2}$ \\ ${ }^{1,2}$ STKIP Kusuma Negara Jakarta \\ Jl Raya Bogor Km 24 Cijantung Jakarta Timur \\ * Corresponding Author:dyah@stkipkusumanegara.ac.id
}

\begin{abstract}
Info Artikel
Abstract

Sejarah Artikel:

Diterima: 02/09/2020

Direvisi: 24/09/2020

Disetujui:29/09/2020

Keywords:

Mathematics Learning

Outcomes, Realistic

Mathematics

Education

$(R M E)$,

multiplication material

The low learning outcomes about mathematics are the background of research problems. The purpose of this study was to improve the mathematics learning outcomes of multiplication material through the Realistic Mathematics Education (RME) learning model for grade III students in the even semester of the 2019/2020 school year. This research method is Classroom Action Research which follows the model of Kemmis and Taggart. This research includes 3 cycles where each cycle includes 4 stages, namely planning, implementing, observing and reflecting. The research time was from January to March 2020 with 30 students as research subjects, while the data were collected through tests, interviews and observations. The research results show that there is a significant increase in mathematics learning outcomes in class III. This is evidenced by the increase in the average result of the math test in each cycle, namely in cycle 1: 64.26 then cycle 2: 70.86 and cycle 3: 78.2. The results of researcher's observations in each cycle also increased, namely in cycle $1=2.44$; cycle $2=$ 2.88; cycle $3=3.89$. Likewise, the results of student observations also increased, namely in cycle $1=2.4$; cycle $2=3,2$; cycle $3=4$. And the results of the interviews conducted concluded that learning mathematics through the Realistic Mathematics Education (RME) learning model was fun for students. This study concluded that learning mathematics using the Realistic Mathematics Education (RME) learning model can improve student mathematics learning outcomes on multiplication material.
\end{abstract}

\begin{abstract}
Abstrak
Rendahnya hasil belajar tentang matematika yang menjadi latar belakang permasalahan penelitian. Tujuan Penelitian ini adalah untuk meningkatkan hasil belajar matematika materi perkalian melalui model pembelajaran Realistic Mathematics Education (RME) pada siswa kelas III semester genap tahun pelajaran 2019/2020. Metode penelitian ini adalah Penelitian Tindakan Kelas yang mengikuti model Kemmis dan Taggart. Penelitian ini mencakup 3 siklus dimana masing-masing siklus mencakup 4 tahap yaitu perencanaan, pelaksanaan, pengamatan/ observasi dan Refleksi. Waktu penelitian yaitu dari bulan Januari sampai bulan Maret 2020 dengan subyek penelitian sebanyak 30 siswa sedangkan data dikumpulkan melalui tes, wawancara dan observasi. Hasil peneltian menunjukkan bahwa terjadi peningkatan hasil belajar matematika yang signifikan pada kelas III. Hal ini dibuktikan dengan persentase hasil rata-rata tes matematika pada setiap siklus meningkat yaitu pada siklus $1: 64,26$ kemudian siklus $2: 70,86$ dan siklus $3: 78,2$. Hasil observasi peneliti pada tiap siklus pun meningkat yakni pada siklus $1=2,44$; siklus $2=2,88$; siklus $3=3,89$. Begitu pula dengan hasil observasi siswa juga mengalami peningkatan yakni pada siklus $1=2,4$; siklus $2=3,2$; siklus $3=4$. Dan hasil wawancara yang dilakukan menyimpulkan bahwa belajar matematika melalui model pembelajaran Realistic Mathematics Education (RME) adalah menyenangkan bagi siswa.Penelitian ini menyimpulkan bahwa belajar matematika dengan menggunakan model pembelajaran Realistic Mathematics Education (RME) dapat meningkatkan hasil belajar matematika siswa pada materi perkalian.
\end{abstract}

\footnotetext{
"Alamat korespondensi:

STKIP Kusuma Negara Jakarta

Jl Raya Bogor Km 24 Cijantung Jakarta Timur

E-mail : dyah@stkipkusumanegara.ac.id
}

(C) 2020 Program Studi PGSD Universitas Flores Email: primagistrauniflor@gmail.com 


\section{PENDAHULUAN}

Sekolah Dasar merupakan tempat
pembelajaran untuk mendapatkan
pengetahuan-pengetahuan dasar tentang
konsep-konsep maupun prinsip
pengembangan sikap kritis dan kreatif dimana
kemampuan ini menjadi pijakan dalam
menempuh jenjang pendidikan lanjutan
sampai ke Perguruan Tinggi.

Guru dalam mengajar matematika seharusnya melalui proses belajar yang terencana dan berpola. Dalam merencanakan proses pembelajaran sekurang-kurangnya meliputi tujuan pencapaian, materi pembelajaran, siswa, media/alat pembelajaran, metode/pendekatan/strategi yang akan digunakan, dan waktu pembelajaran. Hal ini tanpa mengkesampingkan faktor yang lain. Kualitas dan produktivitas pembelajaran akan tampak ketika siswa mencapai tujuan pembelajaran yang ditetapkan, hal ini terkait dengan model/pendekatan/strategi yang dilaksanakan guru. Oleh karena itu, dalam menyampaikan pelajaran harus diorganisir dengan baik dikolaborasikan dengan model/pendekatan/strategi yang tepat agar hasil belajar siswa sesuai dengan yang diinginkan. Sehubungan dengan hal tersebut, pada penelitian ini menggunakan pendekatan pendidikan matematika realisti (PMR) yang dimulai dari masalah kontektual untuk meningkatkan proses dan hasil belajar, dan pelaksanaannya disesuaikan dengan langkah PMR tersebut.

Matematika menjadi mata pelajaran yang dianggap sering mengajak pendidik untuk mengidentifikasi faktor utama permasalahan serta mengkomunikasikan ide ide pemecahan masalah. Mata pelajaran matematika merupakan salah satu mata pelajaran yang diberikan di Sekolah Dasar. Mata pelajaran ini diberikandi kelas I sampai kelas VI. Tujuan mata pelajaran matematika adalah untuk membentuk manusia yang baik, yang dapat mempelajari segala sesuatu yang ada hubungannya dengan hitungan dari yang sederhana sampai yang cukup rumit serta dapat memecahkan masalah-masalah yang dihadapi dalam kehidupan sehari-hari dengan cerdas dan bijaksana. Berdasarkan tujuan di atas, mata pelajaran matematika sangat penting untuk dikuasai siswa karena memiliki nilai fungsional yang tinggi.

Pembelajaran matematika realistik pada dasarnya adalah pemanfaatan realitas dan lingkungan yang dipahami peserta didik untuk memperlancar proses pembelajaran matematika, sehingga mencapai tujuan pendidikan matematika secara lebih baik dari pada yang lalu. Gravemeijer (1994: 82), mengungkapkan bahwa realistic mathematics education is rooted in freudenthal's interpretation of mathematics as an activity. Maknanya adalah pendidikan matematika realistik yang bersumber dari Freudhental menginterpretasikan bahwa matematika sebagai suatu aktivitas. Hal ini berarti bahwa dalam mempelajari matematika dituntut keaktifan bagi yang mempelajari, yang dimaksud disini adalah siswa. Siswa dalam mempelajari matematika harus dikaitkan dengan hal yang nyata. Hal nyata yang dimaksud yaitu situasi yang dialami siswa sehari-hari di lingkungannya. Selain itu, peran hal nyata adalah sebagai awal mula pembelajaran sehingga siswa melakukan matematisasi. Konsep matematika muncul dari proses matematisasi yaitu dimulai dari penyelseian yang berkaitan dengan konteks. Aktivitas siswa dari penyeleseian matematika dapat mendorong interaksi di kelas, oleh karena itu secara tidak langsung membawa siswa kedalam level berfikir matematik yang lebih tinggi.

Menurut Van Reeuwijk (Drijvers, P. 2000: 191-192), karakakteristik RME adalah menggunakan konteks 'real' world, free productions and constructions, mathematization, interaction and integrated learning strands, adapun penejlasannya sebagai berikut :

1) Real world

hal ini menunjukkan bahwa dunia nyata" tidak hanya sebagai sumber matematisasi, dan wadah untuk menerapkan matematika, akan tetapi siswa dapat mendapatkan pengetahuan yang bermakna dari cara sendiri melalui kehidupan nyata.

2) Free productions and constructions, dengan bimbingan guru, siswa diberikan kesempatan untuk mengembangkan pengetahuan informal mereka. Strategi 
informal dapat berupa langkah pemecahan masalah kontekstual, untuk mengkonstruksi pengetahuan matematika formal.

\section{3) Mathematization}

Mengatur model matematika dengan matematisasi progresif. Terdapat dua matematisasi yaitu matematisasi horizontal yang mengacu pada pemodelan situasi masalah pada matematika dan matematisasi vertikal mengacu pada proses matematika yang lebih tinggi.

4) Interaction

Dalam langkah ini interaksi sesama siswa dan antara siswa dengan guru. Interaksi menjadi sangat penting karena interaksi meningkatkan proses matematisasi.

5) Menggunakan (intertwinment)

keterkaitan

Pengitegrasian unit-unit matematika menjadi penting dalam RME. Dalam pembelajaran dikaitkan dengan bidang lain sebagai upaya dalam penyelesaian masalah. Siswa dalam menerapkan matematika dibutuhkan pengetahuan yang komplek artinya tidak hanya dibidang matematika saja, akan tetapi dibidang lain.

Pada RME, dunia nyata digunakan sebagai titik awal dalam mengembangkan ide dan konsep matematika. Dunia nyata merupakan segala sesuatu diluar dari matematika. Pada kehidupan sehari-hari siswa sering menemukan dan melakukan konsep matematika, seperti pada pengukuran dan transaksi jual beli

Lemahnya proses pembelajaran tersebut karena disebabkan suatu pandangan yang mengharuskan bahwa pelajaran harus diselesaikan pada waktu yang ditentukan, sehingga pembelajaran berlangsung secara tradisional dengan mengabaikan hal yang sangat prinsip, dengan metode ceramah yang menjadi pilihan utama dalam pembelajaran. Padahal mata pelajaran matematika tidak dapat dihafal, namun harus dipahami. Untuk anak-anak di kelas rendah dalam mempelajari perkalian harus ditanamkan konsep yang benar agar siswa tidak ragu dalam menerapkan dalam kehidupan sehari-hari. Siswa harus memperoleh pengalaman belajar yang utuh dan kokoh. Informasi yang benar harus diberikan kepada siswa sejak dini karena informasi yang masuk pertama kali akan menjadi memori sepanjang hayatnya.

Namun, berdasarkan pada pengalaman mengajar, dalam proses kegiatan belajar mengajar di kelas mengalami beberapa kelemahan sehingga pemahaman siswa tentang materi pembelajaran matematika khususnya perkalian menurun dan prestasi belajarnya kurang memuaskan. Kelemahan menerima informasi, siswa dipaksa untuk mengingat berbagai informasi tanpa dituntut untuk memahami informasi yang diingatnya itu untuk dihubungkan dengan kehidupan nyata sehari-hari.Beberapa faktor penting yang menyebabkan tujuan sebuah pembelajaran menjadi benar-benar tercapai yaitu metode pembelajaran, cara memotivasi siswa dan kreatifitas guru. Dalam beberapa masalah banyak siswa merasa bosan dengan pembelajaran tanpa media belajar yang nyata atau alat peraga pendidikan. Ditambah dari faktor guru yang kurang memahami penggunaan metode yang tepat guna

Berdasarkan hasil observasi yang dilakukan peneliti di SDN Ciputat 01 Kota Tangerang Selatan pada tanggal 16 Januari 2020 di kelas III dengan jumlah siswa 30 siswa yang menerapkan kurikulum KTSP dan menetapkan kriteria ketuntasan minimal (KKM) untuk kompetensi inti pengetahuan mata pelajaran Matematika adalah 70. Dan pada pembelajaran Matematika, guru menggunakan metode ceramah, tanya jawab, dan pemberian tugas. Metode tersebut dianggap efektif namun hasil belajar siswa dinilai masih kurang. Metode pembelajran tersebut belum mampu memberikan ketertarikan, memotivasi, mengaktifkan serta membangun kreatifitas kepada para siswa.

Hasil belajar sebagian besar siswa

kelas III SDN Ciputat 01 Kota Tangerang Selatan tidak memenuhi KKM. Dari seluruh siswa yang berjumlah 30 siswa, hanya 23,33\% yang tuntas, sedangkan $76,66 \%$ lainnya belum tuntas. Artinya, masih banyak siswa yang belum memahami materi pembelajaran yang diajarkan. Hal tersebut terjadi karena guru dalam pembelajaran Matematika menggunakan metode ceramah, tanya jawab dan pemberian tugas. Metode tersebut dirasa cukup namun nyatanya hasil belajar siswa 


\section{Dyah Anungrat Herzamzam dan Ilmi Noor Rahmad \\ Penerapan Realistic Mathematics Education (RME) di Sekolah Dasar \\ Prima Magistra: Jurnal Ilmiah Kependidikan Volume 1, Nomor 2, Oktober 2020, hal 184-190}

dinilai masih kurang optimal dan masih banyak didapati siswa yang nilainya dibawah KKM.

Proses belajar mengajar sebaiknya dilandasi dengan prinsip-prinsip yang berpusat kepada siswa, mengembangkan kreatifitas siswa, menciptakan kondisi belajar yang aktif dan bermakna juga menyediakan pengalaman belajar yang beragam. Berdasarkan hal tersebut, guru maupun siswa di sekolah dasar memerlukan adanya inovasi pembelajaran untuk meningkatkan hasil belajar siswa. Salah satu model pembelajaran yang dapat dikembangkan adalah model pembelajaran matematika realistik atau dikenal dengan istilah Realistic Mathematich Education (RME).

Purwanto (2011: 54), hasil belajar adalah perubahan perilaku yang terjadi setelah megikuti proses belajar mengajar sesuai dengan tujuan pendidikan.” Manusia mempunyai potensi perilaku kejiwaan yang dapat dididik dan diubah perilakunya yang meliputi domain kognitif, afektif, dan psikomotor. Senada dengan pendapat diatas, Depdiknas (2006), bahwa hasil belajar adalah pencapaian hasil belajar siswa dalam bentuk profil yang mencakup ranah kognitif, psikomotorik, dan afektif. Menurut Hamzah B. Uno (2009: 139), hasil belajar siswa pada mata pelajaran matematika merupakan hasil kegiatan dari belajar matematika dalam bentuk pengetahuan sebagai akibat dari perlakuan atau pembelajaran yang dilakukan siswa. Dengan kata lain, hasil belajar matematika merupakan apa yang diperoleh siswa dari proses belajar matematika. Artinya bahwa hasil belajar matematika merupakan hasil kegiatan dari belajar matematika dalam bentuk pengetahuan sebagai akibat dari perlakuan atau pembelajaran yang dilakukan siswa. Berdasarkan pendapat diatas tentang hasil belajar dapat disimpulkan bahwa: Hasil belajar matematika adalah perolehan kemampuan siswa sebagai hasil dalam mengikuti proses pembelajaran matematika. Dalam hal ini hasil belajar sebagai tolak ukur keberhasilan belajar.

Terdapat beberapa klasifikasi hasil belajar. Benyamin Bloom dalam Nana Sudjana (2010: 2), mengklasifikasikan hasil belajar dalam tiga ranah yakni ranah kognitif, ranah afektif dan ranah psikomotorik, namun yang sesuai dengan penelitian ini maka difokuskn pada ranah kognitif. Ada enam aspek dalam ranah kognitif:

a) Tipe hasil belajar pengetahuan, Dalam bagian ini mencakup ingatan yang pernah dipelajari dan disimpan dalam ingatan.

b) Tipe hasil belajar pemahaman, Pada bagian ini mengacu pada kemampuan memahami suatu materi.

c) Tipe hasil belajar aplikasi, Tipe belajar aplikasi menitik beratkan pada kemampuan penerapan materi atau bahan pelajaran yang telah diperoleh pada situasi yang baru serta berkaitan dengan penggunaan prinsip dan aturan.

d) Tipe Hasil belajar analisis, Pada bagian ini dilihat pada kemampuan dalam penguraian materi dan dapat mengetahui keterkaitan antara bagian satu dengan bagian yang lain. Selain itu, struktur dan aturan dari materi dapat dipahami.

e) Tipe hasil belajar sintesis, Dalam bagian ini mengacu pada kemampuan mensinergikan atau menyatukan komponen agar terbentuk pola atau struktur baru.

f) Tipe hasil belajar evaluasi, Pada tipe evaluasi yang dilihat pada kemampuan pemberian keputusan terhadap nilai-nilai yang dilihat dari beberapa segi seperti tujuan, cara kerja, pemecahan masalah dan sebagainya.

Pengukuran hasil belajar menurut Suharsimi Arikunto (2009: 33), ditinjau dari segi kegunaan untuk mengukur siswa, maka dibedakan atas adanya 3 macam tes, yaitu: tes diagnostik, tes formatif, dan tes sumatif." Setiap tes dilaksanakan dalam waktu dan kegunaan yang berbeda sesuai dengan kondisi dan kebutuhannya, tetapi memiliki tujuan yang sama yaitu untuk mengetahui hasil belajar yang telah dilaksanakan. Terdapat berbagai macam cara untuk mengukur hasil belajar. Dalam mengukur hasil belajar dilihat dan disesuaikan dengan kondisi dan kebutuhan yang akan diteliti.

Menurut Syaifudin Azwar (2011: 1821), prinsip dasar tes hasil belajar adalah:

1) Tes harus mengukur hasil belajar telah dibatasi secara jelas sesuai dengan tujuan instruksional. 
2) Tes hendaknya mengukur suatu sampel yang representatif dari hasil belajar, dan dari materi yang dicakup oleh program instruksional atau pengajaran.

3) Tes hendaknya memuat butir-butir atau item-item dengan tipe yang paling cocok guna mengukur hasil belajar yang diinginkan.

4) Tes hendaknya dirancang sedemikian rupa sesuai dengan tujuan penggunaan hasilnya.

5) Tes hendaknya diusahakan setinggi mungkin dan hasil skornya ditafsirkan secara cermat.

6) Tes hendaknya dapat digunakan untuk memperbaiki dan meningkatkan belajar siswa.

Menurut Nana Sudjana (2010: 5), penilaian proses dan hasil belajar dapat ditingkatkan melalui teknik tes dan non tes. Teknik tes dapat berupa tes tertulis, tes lisan, dan tes praktik atau tes kinerja. Teknik non tes dapat berupa observasi penugasan perorangan atau kelompok, angket, dan bentuk lain yang sesuai dengan karakteristik kompetensi dan tingkat perkembangan peserta didik.

Berdasarkan pendapat diatas dapat diambil kesimpulan bahwa cara mengukur hasil belajar dapat digunakan dengan dua cara yaitu teknik tes dan non tes. Tes digunakan untuk mengumpulkan data belajar matematika siswa. Tes diarahkan untuk penggalian informasi yang bervariasi dan berorientasi tingkat berfikir yang lebih tinggi. Objek belajar matematika yang luas membutuhkan tes yang terbuka dan memberikan kesempatan yang lebih luas bagi siswa yang menunjukkan bagian kompetensi matematis yang telah dan belum dikuasai siswa.

Sesuai dengan uraian di atas, maka Tujuan Penelitian ini adalah untuk meningkatkan hasil belajar matematika materi perkalian melalui model pembelajaran Realistic Mathematics Education (RME) pada siswa kelas III SDN Ciputat 01 Kota Tangerang Selatan semester genap tahun pelajaran 2019/2020.

\section{METODE PENELITIAN}

Penelitian ini merupakan penelitian tindakan kelas (classroom action reseasch) yang digunakan untuk mengubah kondisi nyata sekarang kearah kondisi yang diharapkan. Oleh karena itu, penelitian ini bertujuan untuk meningkatkan hasil belajar matematika menggunakan RME. Penelitian ini dilakukan secara kolaboratif, artinya dalam penelitian ini peneliti bersama dengan guru sejak perenungan menentukan masalah, planning (perencanaan), acting (tindakan), observing (observasi), serta reflecting (refleksi). Dalam penelitian ini langkahlangkah penelitian mengacu pada model Kemmis dan Mc Taggart (1988: 11), terdapat 4 tahapan yang lazim dilalui, yaitu (1) perencanaan, (2) pelaksanaan (tindakan), (3) pengamatan (observasi) dan (4) refleksi.

Adapun model masing-masing tahap dapat dilihat sebagai berikut:

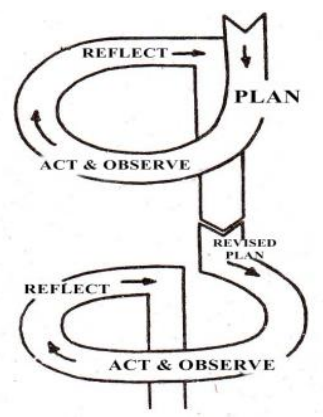

Gambar 1. Tahapan pada siklus Penelitian Tindakan Kelas

Kemmis \& Mc Taggart (1988: 11)

\section{HASIL DAN PEMBAHASAN}

\section{Hasil Penelitian}

Melalui model pembelajaran Realistic Mathematics Education (RME), perbaikan pembelajaran Matematika mengalami perubahan kearah yang lebih baik.

Tabel. 1

Hasil Analisis Ketuntasan Belajar Siswa

\begin{tabular}{lcc}
\hline No & Siklus & Persentase $(\%)$ \\
\hline 1. & Siklus 1 & 64,26 \\
2. & Siklus II & 70,86 \\
3 & Siklus III & 78,2 \\
\hline
\end{tabular}

Dari tabel di atas, siswa yang memenuhi KKM dengan nilai $\geq 75$ adalah sebanyak 20 orang hanya terdapat beberapa siswa yang tidak memenuhi KKM. Hal ini menunjukkan 


\section{Dyah Anungrat Herzamzam dan Ilmi Noor Rahmad \\ Penerapan Realistic Mathematics Education (RME) di Sekolah Dasar \\ Prima Magistra: Jurnal Ilmiah Kependidikan Volume 1, Nomor 2, Oktober 2020, hal 184-190}

bahwa hasil belajar siswa telah mencapai target yang ditetapkan sekolah yaitu minimal 75\% dari jumlah siswa 30. Secara indivudual telah memperoleh nilai minimal 76 secara perorangan dan telah memenuhi kriteria keberhasilan yang telah ditetapkan dalam penelitian ini sehingga penelitian dapat dihentikan pada siklus III.

\section{Pembahasan}

RME dapat meningkatkan hasil belajar siswa. Berdasarkan hasil analisis ketuntasan belajar diketahui bahwa pada siklus I sebanyak $64,26 \%$ telah memenuhi KKM. Setelah dilakukan perbaikan hasil belajar siswa pada siklus II, siswa yang memiliki nilai rendah (belum memenuhi KKM) mengalami peningkatan hasil belajarnya. Pada siklus II, jumlah siswa yang memenuhi KKM sebanyak $70,86 \%$. Pada siklus III, jumlah siswa yang memenuhi KKM sebanyak 78,2\%. Keberhasilan ini tidak lepas dari peran guru dalam memberikan pembelajaran. Guru dalam memberikan pembelajaran telah dijelaskan pada pembahasan sebelumnya.

Siswa dapat meningkat hasil belajarnya karena siswa membangun sendiri pengetahuan matematika. Melalui permasalahan nyata yang diberikan oleh guru. Siswa tidak mudah lupa akan pengetahuan yang diperoleh. Siswa senang dalam mengikuti pembelajaran matematika. Dalam pembelajaran ini siswa tidak dituntut untuk duduk, mendengarkan, menulis rumus, dan latihan soal, akan tetapi siswa berinteraksi dengan siswa lain dan guru, menyampaikan pendapat, dan tampil di depan kelas, serta menggunakan benda nyata yang sering dijumpai siswa dalam kehidupan sehari-hari. Siswa diberikan kesempatan berdiskusi dengan siswa lain, hal ini memupuk kerja sama dalam kelompok, bersosialisasi, dan siswa berani menyampaikan pendapatnya, dan siswa diberikan pendidikan budi pekerti dengan lebih menghormati teman atau guru apabila sedang berbicara. Hal ini sesuai dengan pendapat Asmin (Edy Tandililing 2003 : 3), Kelebihan PMR antara lain : (1) karena siswa membangun sendiri pengetahuannya maka siswa tidak mudah lupa dengan pengetahuannya, (2) susana dalam proses pembelajaran menyenangkan karena menggunakan realitas kehidupan, sehingga siswa tidak cepat bosan belajar matematika, (3) siswa merasa dihargai dan semakin terbuka karena setiap jawaban siswa ada nilainya, (4) memupuk kerjasama dalam kelompok, (5) melatih keberanian siswa karena harus menjelasakan jawabannya, (6) melatih siswa untuk terbiasa berfikir dan mengemukakan pendapat, (7) pendidikan budi pekerti, misalnya saling kerjasama dan menghormati teman sedang berbicara. Melalui serangkaian kegiatan tersebut mempengaruhi peningkatan hasil belajar siswa.

Selain itu sesuai dengan penelitian Yudha dan Suwarjo (2014: 55) Dampak dari peningkatan Kepercayaan diri dan proses belajar menggunakan PMR tersebut tercermin pada hasil belajar siswa. Hal ini dibuktikan pada siklus I sebanyak 17 siswa atau sebesar 85\% telah memenuhi KKM dan 3 siswa atau sebesar $15 \%$ belum memenuhi KKM. Setelah dilakukan perbaikan proses belajar dan lebih didominasi siswa, hasil belajar siswa pada siklus II meningkat. Pada siklus II, jumlah siswa yang memenuhi KKM sebanyak 20 siswa atau $100 \%$.

\section{SIMPULAN DAN SARAN}

Berdasarkan hasil analisis dan pembahasan penelitian dapat disimpulkan. Kesimpulan dalam penelitian ini adalah sebagai berikut: melalui penerapan RME dapat meningkatkan hasil belajar siswa. Bahwa pada siklus I sebanyak 64,26 \% telah memenuhi KKM. Setelah dilakukan perbaikan hasil belajar siswa pada siklus II, siswa yang memiliki nilai rendah (belum memenuhi KKM) mengalami peningkatan hasil belajarnya. Pada siklus II, jumlah siswa yang memenuhi KKM sebanyak 70,86\%. Pada siklus III, jumlah siswa yang memenuhi KKM sebanyak $78,2 \%$.

\section{DAFTAR PUSTAKA}

Drijvers. P. (2000). Students encountering obstacles using a cas, International Journal of Computers for Mathematical Learning: Kluwer Academic Publishers. 
Edy Tandililing (2003). Implementasi Mathematic Realistik Education $(R M E)$ di sekolah. Artikel. Diambil pada tanggal 13 Oktober 2012, dari

http://jurnal.untan.ac.id/index.php/igm m/article/download/208/202

Gravemeijer, K. (1994). Developing Realistic Mathematics Education. Utrecht: Freudenthal Institute.

Hamzah. B.Uno. (2009). Model pembelajaran (menciptakan proses belajar mengajar yang kreatif dan efektif). Jakarta: Bumi Aksara.

Kemmis \& Mc. Taggart. (1988). The action research planner. Victoria: Deakin University

Nana Sudjana.(2010). Penilaian Hasil Proses Belajar Mengajar. Bandung: PT Remaja Rosdakarya.

Purwanto.(2011). Evaluasi Hasil Belajar. Yogyakarta: Pustaka pelajar

Suharsimi Arikunto. (2009). Dasar-dasar Evaluasi Pendidikan. Jakarta: PT. Bumi Aksara

(2010). Penelitian Tindakan Kelas. Jakarta : Bumi Aksara.

Syaifudin Azwar. (2011). Tes prestasi: Fungsi dan pengembangan pengkururan prestasi belajar. Yogyakarta. Pustaka Pelajar.

Yudha, C.B dan Suwarjo (2014). Peningkatan Kepercayaan Diri Dan Proses Belajar Matematika Menggunakan Pendekatan Realistik Pada Siswa Sekolah Dasar. Jurnal Prima Edukasia. Volume 2 Nomor $142-56$ 